\title{
Increasing Salience of Crime Control in Finnish Parliamentary Data from the 1970 s to the 2000s
}

\author{
ESKO HÄKKINEN *
}

\section{Introduction}

The history of Finnish criminal justice and penal policy has been rather eventful. The first decades after Finland became independent in 1917 were marked by a severe harshness. A phase of restricting the use and severity of punishment followed after the Second World War. It culminated in a series of significant reforms enacted between the late 1960s and the mid-1970s, and the multistage work for the general reform of the Criminal Code begun in 1972. In the 1990s, Finnish criminal justice took a more ambivalent turn. As elaborated below, this latest turn has been analysed from many perspectives in Finnish literature on the criminal justice system. While the restrictive trend did continue in general regulation concerning the penal system itself, sanctions for specific types of crimes-particularly in the areas of drugs, violence, and sex crimes-were made increasingly tough. A demand for crime prevention methods that promised fast and direct results such as zero-tolerance policing emerged. Both the policing and sentencing of drug crimes were tightened. Crime news reports in the media increased. What has been lacking is a systematic study of the political context of the turn.

* Grant researcher, Faculty of Law, University of Helsinki. The work was supported by Finnish Cultural Foundation.

This is an Open-access article distributed under the terms of the Creative Commons Attribution 3.0 Unported License (http://creativecommons.org/licenses/ by/3.0/), permitting all use, distribution, and reproduction in any medium, provided the original work is properly cited. 
This study looks at the political backdrop of the making of Finnish criminal policy. Was the turn in the 1990s associated with a politicisation of the issue of criminal justice? For the purposes of this study politicisation is understood as increased public political attention. This use of the concept is not to imply that criminal justice, as it deals with the distribution of resources in society, is not always inherently political. ${ }^{1}$ At the same time, there is no reason to think that crime should always be high on the on the public agenda, or that it being high on that agenda provides a measure of how democratic criminal justice is. Politicisation is not used here synonymously with what John Pratt has termed 'penal populism': the shift of penal power from the hands of a small elite of criminal justice experts to both the victim movement and elected politicians representing the opinions of the forgotten public. ${ }^{2}$ In the context of this analysis concerning Finland, the historical opposite of politicised criminal justice is not penal elitism, where decision-making concerning criminal justice is insulated from the public analogously to an independent central bank. It is a consensual style of politics in general-in which deliberation and participation have been facilitated through intermediary institutions, the civil society, and preparatory committees - where the public priority of criminal justice as a policy field remained relatively low. In this framework, the turning of public political attention towards criminal justice can be seen as a symptom of the decline of participatory and programmatic politics, which Ian Loader has called the 'anti-politics of crime,', or as the search for social solidarity from penal justice when the social and economic worlds are deregulated. ${ }^{4}$ To the extent that the direct influence of public opinion increases, this is not an increase in the quantity of democracy in criminal justice, but a change in the quality of democracy whereby the public becomes less an agent responsible through participation for the content and effects of policy, ${ }^{5}$ and more an audience judging the performance and credibility of representative politicians.

As data for a content analysis of politicisation, I utilise parliamentary documents, especially written questions by members of parliament. The general policy direction advocated in the analysed political messages will be observed. Patterns of attention given to crime by different parties will be examined, as well as the temporal relationship between changes in political attention and changes in the law. The perspective of the analysis is longitudinally comparative. The economic downturn which hit Finland in 1991 is widely cited as a watershed moment in the development of Finnish society and politics and

1 Shammas, Who's afraid of penal populism? Technocracy and 'the people' in the sociology of punishment, 19 Contemporary Justice Review (2016) pp. 325-346, at 337.

2 Pratt, Penal Populism (Routledge 2007) pp. 8-35. See Loader, The anti-politics of crime, 12 Theoretical Criminology (2008) pp. 399-410, at 404.

$3 \quad$ Loader 2008 pp. 404-406.

$4 \quad$ Durkheim, The Division of Labor in Society (The Free Press 1933).

5 See Dzur, Participatory Democracy and Criminal Justice, 6 Criminal Law and Philosophy (2012) pp. $115-129$, at $120-123$. 
the above-mentioned changes concerning Finnish criminal justice in the 1990s mostly did not start taking place before that point in time. The study encompasses developments during four decades from the 1970s to the 2000s-the two decades both leading to and following this hypothesised turning point in the beginning of the 1990s. The main emphasis of this study is in legal history and description. However, after presenting the framework, method, and results of the analysis, and my conclusions concerning the research question, I discuss in more theoretical terms the connections between the turn in criminal justice and changes in the Finnish political structure. It has, I argue, lost some of the characteristics which formerly made it a highly consensual democracy.

\section{Falling Imprisonment Rates and the Turn in the 1990s}

The research question of this study arises largely from previous Finnish research, which this section presents. However, I will first briefly frame the study cross-comparatively to lay out its general approach. Academic understanding tends to be that Western crime control has, in general, taken a direction towards increasing punitivity during the last half a century. Many comparatists have, however, pointed out large differences between Western countries. One of these differences is illustrated by the thesis of Nordic exceptionalism, perhaps most associated with Pratt. Pratt claims that the punitive wave has reached the Nordic welfare states only faintly if at all, and that, in fact, the Nordic countries seem more exceptional in their penal leniency than ever, comparatively speaking. This outside comparatist view tends to clash with the internal perspective of the tradition of Nordic critical penology. The outside view's ability to understand the nuances of Nordic penality has been questioned. Anglophone researchers are accused of projecting their scholarly hopes onto the Nordic countries seen by them as exotic, if not utopian. ${ }^{6}$ Much of the critical school that looks at the Nordic countries from within works from a Foucauldian theoretical framework, which emphasises the explanatory power of technological change and often finds similar developments in societal control in various places. According to this school, in the advanced liberalism of late modernity, social technologies of choice include the biological managing of human bodies, governing from a distance, and encouraging individual self-regulation and responsibility. ${ }^{7}$

The Nordic welfare state, which supposedly protects the Nordic countries from punitive trends, could be seen as actually creating control. For example, underdeveloped

$6 \quad$ See Dullum and Ugelvik, Introduction: exceptional prisons, exceptional societies? in Penal Exceptionalism? Nordic prison policy and practice, eds. Ugelvik and Dullum (Routledge 2012) pp. $1-10$.

7 Borch, Crime Prevention as Totalitarian Biopolitics, 6 Journal of Scandinavian Studies in Criminology and Crime Prevention (2005) pp. 91-105. 
individual rights and legal safeguards reflecting the paternalistic logic of the welfare state model may allow abuses such as the excessive use of separate confinement in pre-trial detention. ${ }^{8}$ Peter Scharff Smith and Thomas Ugelvik, asking how welfarist Nordic prisons are, acknowledge that that they are closer to the ideal type of an inclusive and rehabilitative institution than prisons in many other Western countries. Nevertheless, they conclude that Nordic prisons are more aptly characterised by invasive paternalism, double-faced normalisation, and resorting to exclusion when other means fail. Prisons are always prisons. ${ }^{9}$

Probably the least controversial fact is that imprisonment rates vary greatly between Western countries, with the Nordic countries being at the lenient end and the United States, with its rates up to ten times higher, being at the other. We should differentiate between two arguments: one is that in the Nordic countries the inclusive welfare state has functioned as an alternative to exclusionary penal policy; the other is that punishment itself is welfarist in the Nordic countries. As I see it, the argument that the comparative works which highlight Nordic exceptionalism most speak for is the first one. This, of course, was the message of Nordic neoclassicism in the 1970s: prisons are indeed not turning into welfare institutions; punishment should be kept separate from social policy and its use restricted. This is where the success of Nordic prison policy has been, while the moral failures have usually occurred when attempts have been made to mix the two. The starting point of this analysis is that there can be meaningful comparative differences in harshness between penal systems both in time and across countries that can be fruitfully explained by their normative institutional contexts.

However, in their chief work concerning the exceptionalism thesis, Pratt and Anna Eriksson argue that the relationship between the Nordic welfare state model and lenient penal policy is only a proximate correlation, and that the real explanations common to both are cultural. Because of a long history of class and emigration dynamics, religious beliefs, and education systems that have fostered social cohesion and statism, Nordic people are culturally inclusive and egalitarian. ${ }^{10} \mathrm{My}$ theoretical stance is against the deep cultural determination of Pratt and Eriksson and in favour of the institutionalism they dismiss as shallow. At least in terms of imprisonment rates, the history of Nordic exceptionalism is not particularly long, ${ }^{11}$ and the case of Finland gives evidence that Nordic

8 Smith, A critical look at Scandinavian exceptionalism: welfare state theories, penal populism and prison conditions in Denmark and Scandinavia, in Penal Exceptionalism? Nordic prison policy and practice, eds. Ugelvik and Dullum (Routledge 2012) pp. 38-57.

9 Smith and Ugelvik, Punishment and Welfare in Scandinavia, in Scandinavian Penal History, Culture and Prison Practice. Embraced by the Welfare State? eds. Smith and Ugelvik (Palgrave Macmillan 2017) pp. 511-529.

10 Pratt and Eriksson, Contrasts in Punishment. An Explanation of Anglophone Excess and Nordic Exceptionalism (Routledge 2013).

$11 \quad$ See ibid p. 6. 
people have been culturally quite capable of harshness. ${ }^{12}$ In Scandinavia, the development of the welfare state had a profound impact on criminal policy, which in turn affected the harshness of punishment. ${ }^{13}$ This was repeated in Finland, although later and with a much higher starting level of both social conflict and penal exclusion.

As best exemplified by the civil war in 1918, post-independence Finland was, in political terms, anything but harmonic. Through the 1920s, 1930s, and 1940s, criminal justice remained remarkably severe, with imprisonment rates regularly exceeding 200 per 100,000 inhabitants. ${ }^{14}$ Penal policy started to ease in Finland when its institutional background transformed: extreme political conflict abated, the trade union movement was recognised in the neo-corporatist vein, and, as a result, the Finnish welfare state began to develop. Sentencing practices started to ease rapidly, and later the Social Democratic Party in particular started to advocate for a full reform of the criminal justice system. ${ }^{15}$ Numerous changes decreasing the use of prison were made to Finnish criminal law, especially in the period lasting from the late 1960s to the mid-1970s. ${ }^{16}$ A committee was established in 1972 to prepare a general reform of the Criminal Code, releasing its report

12 Cf. ibid pp. 6-7. See fig. in ibid p. 6.

13 Nilsson, "First We Build the Factory, Then We Add the Institution": Prison, Work and Welfare State in Sweden c. 1930-1970, in Scandinavian Penal History, Culture and Prison Practice. Embraced by the Welfare State? eds. Smith and Ugelvik (Palgrave Macmillan 2017) pp. 35-56, at 39-42; Shammas, Prisons of Labor: Social Democracy and the Triple Transformation of the Politics of Punishment in Norway, 1900-2014, in Scandinavian Penal History, Culture and Prison Practice. Embraced by the Welfare State? eds. Smith and Ugelvik (Palgrave Macmillan 2017) pp. 57-80. See also Fransen, The Rise of the Open Prisons and the Breakthrough of the Principle of Normalisation from the 1930s Until Today, in Scandinavian Penal History, Culture and Prison Practice. Embraced by the Welfare State? eds. Smith and Ugelvik (Palgrave Macmillan 2017) pp. 81-102. For a Foucauldian analysis of criminal policy as a part of social democratic governance see Andersson, A Culture of Intervention-Vagrancy and Drug Treatment in Sweden from the Late 19th Century Until Today, in Scandinavian Penal History, Culture and Prison Practice. Embraced by the Welfare State? eds. Smith and Ugelvik (Palgrave Macmillan 2017) pp. 103-125. Both Nilsson and Andersson emphasise the role of work and the striving for high employment rates as a connecting element between the development of the welfare state and punishment in Sweden.

14 See Hannula, Rikosoikeudellinen järjestelmä kriisissä. Tutkimus kansalaissodan ja 1930-luvun alun kriisin vaikutuksesta vankilukuun, rikoslainsäädäntöön ja oikeudenkäyttöön [Criminal justice system in crisis. Analysis of the effect of civil war and the crisis of the early 1930s on imprisonment rate, criminal law, and the administration of justice] (Suomalainen Lakimiesyhdistys 2004).

15 Lappi-Seppälä, Kriminaalipolitiikan muutostrendejä [Trends in the direction of criminal policy], in Rikosoikeuden muutos 1960-luvulta 2010-luvulle. Pekka Koskisen (1943-2011) muistojulkaisu, ed. Lahti (Forum iuris 2013) pp. 17-52, at 20-22.

16 Lappi-Seppälä, Vaikuttivatko lainmuutokset? Pohdintoja rikosoikeudellisen järjestelmän muutosvaikutuksista [Did legislative changes make a difference? Reflections on the transformative effects of the criminal justice system], in Lainvalmistelu, tutkimus, yhteiskunta. Jyrki Talan juhlakirja, eds. Pakarinen, Hyvärinen, and Ervasti (Turun yliopisto 2011) pp. 165-206. 
in 1977. The codification of this new, less punitive approach to criminal justice continued in the Criminal Code Project, which began in 1980.

The restrictive trend in sentencing came to an end in the 1990s, in what Tapio Lappi-Seppälä calls a punitive turn. The measured and comprehensive development of criminal law switched to a series of toughening law reforms, particularly in the areas of drugs, violence, and sex crimes. The turn, however, was not a straightforward one, as reforms of the penal system that limited the use of imprisonment continued through the 1990s and 2000 s. ${ }^{17}$ Sentencing became harsher, especially regarding violent crimes and drug offences. The raising of the minimum sentence for aggravated assault from six to twelve months had the largest single impact on the penal system. The average sentence for aggravated assault rose by approximately six months between 1998 and 2004, and the length of prison sentences for all violent crimes rose by 70 percent during the same period. ${ }^{18}$ Imprisonment rates reached a 17-year high of 74 per 100,000 in 2004, but fell back down to 61 per 100,000 in 2010. Offence specific changes and court praxis first raised the imprisonment rate, and reforms of the sentencing system in general then reduced it.

Several scholars have concluded that what characterised the 1990s was a transition from holistic, social crime control towards more superficial methods of crime prevention. ${ }^{19}$ The combination of patience with regulation that reflected ideas of social responsibility for crime diminished. Concern about public drinking by youths led to a trial of zero-tolerance policing in the city of Tampere. Problems which used to be considered social were being redefined as problems of law and order. Acceptance of the inconvenience caused to decent citizens decreased, for example, in the prevention of alcohol-related harm. ${ }^{20}$ The security strategies of the city of Helsinki echoed zero-tolerance attitudes also, where fighting graffiti became a particular preoccupation. A national crime prevention

$17 \quad$ Lappi-Seppälä 2013 pp. 25-36.

18 Lappi-Seppälä, Rangaistuskäytännön hinta [The cost of sentencing practice] (Tiede, taide ja köyhä kansa 2007).

19 Harrikari, Riskillä merkityt. Lapset ja nuoret huolen ja puuttumisen politiikassa [Labelled with risk. Children and youth in the politics of concern and intervention] (Nuorisotutkimusverkosto 2008) pp. 115-118; Kekkonen, "Sosiaalipolitiikka on parasta kriminaalipolitiikkaa" ['Social policy is the best criminal policy'], in Rikosoikeudellisia kirjoituksia VII. Pekka Koskiselle 1.1.2003 omistettu, eds. Lahti and Lappi-Seppälä (Suomalainen Lakimiesyhdistys 2003) pp. 115-126; Koskela, Pelkokierre. Pelon politiikka, turvamarkkinat ja kamppailu kaupunkitilasta [Spiral of fear. The politics of fear, security markets and the struggle for urban space] (Gaudeamus 2009).

20 Korander, Arvioyhteenveto: miten käy, kun poliisi ei siedä häiriökäyttäytymistä? [Evaluation summary: what happens when the police do not tolerate disorderly conduct?] in Kahdeksalta koskarille-samantien sakot. Tampereen nollatoleranssikokeilu 1999-2000: Historiallinen konteksti, vastaanotto ja vaikuttavuus, eds. Korander and Soine-Rajanummi (Poliisiammattikorkeakoulu 2002) pp. 400-420. 
programme incorporated public-private partnerships, zero-tolerance, and situational crime prevention into the traditional logic of social prevention. ${ }^{21}$

Regarding specific types of offences, the rise on the agenda of drugs and white-collar crime have received the most analysis in Finnish literature. Anne Alvesalo considers that the attention paid to economic crime in Finland in the 1990s is peculiar from a comparative perspective. Plans, programmes, and reforms concerning economic crime control abounded. Police officers and prosecutors were assigned to specialise in white-collar crime, and enforcement was intensified. Cuts to social spending while banks were being bailed out during the economic recession of the 1990s gave legitimacy to the prevention of economic crime and opened a window for the realisation of the groundwork laid down in committees and academic research in the previous decades. Despite increases in resources and specialisation, work against economic crime never got far from the fringes of policing, and enthusiasm for it waned when the end of the decade started to near. According to Alvesalo, associating economic crime with drugs offered an opportunity to draw attention away from the prevention of white-collar crime, which inconvenienced the most well-off, back to the controlling of mass crime. ${ }^{22}$

The association of the drug problem with organised crime was, in part, an effect of international agreements. Police control of drugs became tighter in the 1990s and increasingly targeted users. Drugs were also being used as grounds for the enhancement of police powers. The number of drug-related sentences increased in the 1990s, and judicial custom became extraordinarily severe relative to sentencing scales. In the drug enforcement field, police started to operate in ways that somewhat deviated from traditional Finnish policing by, for example, maintaining close connections with collaborating informants. ${ }^{23}$

Narcotics offences were integrated into the Criminal Code as part of the general reform at the beginning of the 1990s. In line with the general structure of the code, a preparatory working-group had proposed a mitigated form of drug offence which would have included drug use. Lenient treatment of drug use turned out to be an unacceptable idea in the views of the minister of justice and the police, and the suggestion was left out of the government's proposal and the enacted law. Whether drug use should be kept criminalised in the first place was questioned by no one in the parliamentary debate, unlike during previous reforms of drug laws in the 1970s. A special provision making it possible to drop prosecution in cases of use was added, however, which caused discontent, espe-

$21 \quad$ Koskela, 2009 pp. 235-298.

22 Alvesalo, The Dynamics of Economic Crime Control (Poliisiammattikorkeakoulu 2003) pp. 11, $17-24,42-47,52-61$.

23 Kinnunen, Kriminaalipolitiikan paradoksi. Tutkimuksia huumausainerikollisuudesta ja sen kontrollista Suomessa [The paradox of criminal policy. Analyses of drug crime and its control in Finland] (Oikeuspoliittinen tutkimuslaitos 2008) pp. 70-73, 79-85, 102. 
cially among the police. Therefore, drug use was later separated into a separate offence, which for technical reasons made giving fines easier at the expense of the practice of non-prosecution. ${ }^{24}$

Claims of a change in the political atmosphere have usually been supported by anecdotal examples. Lappi-Seppälä cites a comment by the justice minister in the late 1990s about 'the criminal policy of the 1970s' having reached the end of its road, as well as similar media statements by the then prosecutor general Martti Kuusimäki. ${ }^{25}$ The presidential New Year's speech of 1998 dealing with the safety of streets and public security as a campaign theme in the elections of the early 2000s have likewise been mentioned. ${ }^{26}$ More extensive political data has been utilised in limited analyses of economic crime control, ${ }^{27}$ drug control, ${ }^{28}$ and changing political discourse concerning children and youth. ${ }^{29}$ The increase in the media's crime coverage has been dealt with in several studies. ${ }^{30}$ In this analysis, the politicisation of crime control is studied systematically using longitudinal political data without restrictions of the aforementioned kind. The addition of a party-political perspective is also a novel addition to research on Finnish criminal policy. ${ }^{31}$

\section{Data and Method}

Parliamentary documents and political programmes are natural primary sources for the analysis of the development of criminal policy. However, Finnish parties have composed few plans of action concerning crime control, and party platforms do not elaborate much on the topic. Accordingly, I have used motions and questions by members of parliament in general, and written questions in particular, as data. Analysis of parliamentary questions can reveal themes present on the political agenda and rifts concerning them, as well

24 Kainulainen, Huumeiden käyttäjien rikosoikeudellinen kontrolli [Criminal justice control of drug users] (Oikeuspoliittinen tutkimuslaitos 2009) pp. 95-144.

$25 \quad$ Lappi-Seppälä 2013 p. 26.

$26 \quad$ Koskela, 2009 pp. 14, 234-235.

27 Alvesalo and Tombs, Talousrikostorjunnan rajat [The limits of economic crime prevention], 30 Oikeus (2001) pp. 34-55.

$28 \quad$ Kainulainen 2009.

$29 \quad$ Harrikari 2008.

30 See Smolej and Kivivuori, Crime News Trends in Finland: A Review of Recent Research, 9 Journal of Scandinavian Studies in Criminology and Crime Prevention (2008) pp. 202-219.

31 For Sweden see Demker and Duus-Otterström, Realigning criminal policy. Offender and victim in the Swedish party system over time, 19 International Review of Sociology (2009) pp. 273-296. 
as differences in parties' orientation towards different fields of politics. ${ }^{32}$ The procedural rules concerning the right to introduce motions and present questions have changed many times in the Finnish parliament during the decades that this analysis concerns, which affects the temporal comparability of data. The institution of the written question, however, has remained exceptionally stable. ${ }^{33}$ Despite its name, from a parliamentarian's perspective, a parliamentary question is primarily an opportunity to communicate information rather than to receive it. Thus, I interpreted the questions as statements, and the answers to the questions were not analysed. The diverse and plentiful data enables a comprehensive and systematic diachronic analysis. In the Finnish parliament, practically all parliamentarians traditionally submit written questions, the numbers of questions are distributed relatively evenly between them, and the status of the parliamentarian as an opposition or government supporter has surprisingly little effect on their activity. ${ }^{34}$ The questions do not have a direct connection to governmental activity such as the hearings of governmental proposals, which is an advantage in operationalising politicisation in a fashion that is useful in explaining legislative change. The questions can express general political pressure that might then lead to actions by the government, as opposed to them being merely a consequence of the government already having decided to do something.

I analysed the data using two-stage content analysis. Content analysis is a method of studying texts in an analytical context. Its use is justifiable when analysing phenomena related to language and linguistic occurrence, especially qualities and speech practices attached to an object of study. The results of its application tend to be best when its target is institutional, public, and repetitive. ${ }^{35}$

First, in a mechanical content analysis I quantified all the questions and motions by members of parliament from parliamentary seasons (roughly corresponding to calendar years) 1975 II to 2010 (electoral terms 1975 II to 2007) that have been indexed in the official Finnish parliamentary documents (valtiopäiväasiakirjat/riksdagshandlingar) by one or more descriptors that I interpreted as relating to criminal policy (crime, public order, offenders, victims, crime control, and sanctions). The searches were conducted using the search engine (since revised) on the website of the Finnish Parliament using four indexes

32 Wiberg, Eduskunta hallituksen valvojana: kansanedustajat ovat kyselevinään ja ministerit ovat vastaavinaan [Parliament as government overseer: Parliamentarians feign asking and ministers feign responding], in Eduskunta. Kansanvaltaa puolueiden ja hallituksen ehdoilla, eds. Raunio and Wiberg (Gaudeamus 2014) pp. 203-225, at 221.

33 See Hidén, Juridiikkaa ja muotoja eduskuntatyössä [Jurisprudence and protocols in parliamentary work] (Eduskunta 2007) pp. 94-107.

34 Wiberg, To keep the government on its toes: behavioural trends of parliamentary questioning in Finland 1945-1990, in Parliamentary Control in the Nordic Countries. Forms of Questioning and Behavioural Trends, ed. Wiberg (The Finnish Political Science Association 1994) pp. 103-200, at 139-161.

35 Krippendorff, Content Analysis. An Introduction to Its Methodology, 3rd ed. (SAGE 2013) pp. $27-31,64,77-80$. 
of descriptors, which cover the parliamentary seasons 1975 II to 1986, 1987, 1988, and 1989 to 2014. Descriptors used before 1975 II were unsuitably general for the analysis. A computerised analysis has perfect reliability which comes with the relative sacrifice of validity. ${ }^{36}$ The lack of human interpretation makes the results completely stable and free of errors across repeated analyses, but reduces the exactness by which they measure that what is supposed to be measured: the keywords produce some hits on motions and questions which do not concern criminal policy.

The second content analysis was interpretively coded. ${ }^{37}$ It covered written questions relevant to criminal policy from parliamentary seasons 1970 to 2010 (electoral terms 1970 to 2007). The analysis is a systematic description of the complete sample where each observation was defined using a purpose-made coding frame. The frame had a variable for each of the dimensions being studied. Each question (the unit of analysis) was given one and only one value for each variable. Only relevant questions were analysed. The most important variables in the coding frame for the purposes of this writing were the policy direction (toughening or softening) indicated in the questions and the types of offences the questions concerned.

I selected the relevant questions during the main coding. For the basic selection of questions for the period 1975 II to 2010, I used the same lists of descriptors as in the computerised analysis. For the period 1970 to 1975, I used both index descriptors and question titles for basic selection. Of the 1858 written questions thus selected, I coded 1589 as the relevant data. As with selecting the descriptors, I defined as relevant the questions which I interpreted as dealing with crime, public order, offenders, victims, crime control, and sanctions. In addition, I required that the questions concerned Finnish matters current at the time of the question. I excluded those questions touching on the police and prisons which I interpreted as primarily concerning regional, language, or employment policy instead of criminal policy, as well as questions primarily concerning national security. In practice, coding the questions meant reading each question and inputting values for it according to the coding frame in a data matrix, where each question formed one observation. Technical information such as the party of the first signatory of each question was also recorded. After the main coding, I recoded 10 percent of the data to ensure satisfactory inter-coding agreement (stability) using Scott's pi coefficient. ${ }^{38}$

Ibid pp. 210, 267-270.

See Schreier, Qualitative Content Analysis in Practice (SAGE 2012).

See ibid pp. 166-172, 198-199 


\section{Results}

\subsection{The Politicisation in General}

The results of the computerised content analysis can be given briefly but are central in addressing the basic question of this analysis. In the first content analysis, based on the occurrence of descriptors, the share of crime control themes rose in all types of motions and questions from the 1970s to the 2000s. The turn took place at the beginning of the 1990s (Figures 1 and 2). The turn from a lower level in the 1970s and 1980s to a higher level in the 1990s and 2000s was the clearest in written questions, which can be expected to provide the most systematic results because of their institutional stability. The watershed taking place at the beginning of the 1990s corresponds with the results of studies concerning media coverage of crime themes. The attention given to crime and crime control rose from the 1980s to the 2000s in newspaper editorials, ${ }^{39}$ tabloid headlines, ${ }^{40}$ and television news. ${ }^{41}$ The political backdrop of the making of Finnish criminal policy clearly changed. Public political attention concerning criminal justice, as operationalised here, increased considerably from the 1980s to the 1990s. Crime control was politicised. This does not, however, reveal how punitive the motions and questions were and how their timing corresponded with legislative change. Attempts to elucidate these questions, among others, are made below using the smaller data set of written questions.

39 Kemppi, Pä̈kirjoitusten väkivalta. Tutkimus Helsingin Sanomien pääkirjoitusten väkivaltakommentoinnista vuosina 1980-2000 [Violence in editorials. Analysis of violence commentary in the editorials of Helsingin Sanomat 1980 to 2000], unpublished master's thesis (Helsingin yliopisto 2002).

40 Kivivuori, Kemppi, and Smolej, Etusivujen väkivalta. Väkivalta iltapäivälehtien etusivuilla, todellisuudessa ja ihmisten peloissa 1980-2000 [Violence on front pages. Violence in the front pages of tabloids, in reality, and in the public's fears 1980 to 2000] (Oikeuspoliittinen tutkimuslaitos 2002).

${ }^{41}$ Kemppi and Kivivuori, Rikosuutisoinnin määrä yleisradion television pääuutislähetyksessä 1985-2003 [The amount of crime news in the main newscast of Yleisradio 1985 to 2003] (Oikeuspoliittinen tutkimuslaitos 2004). 


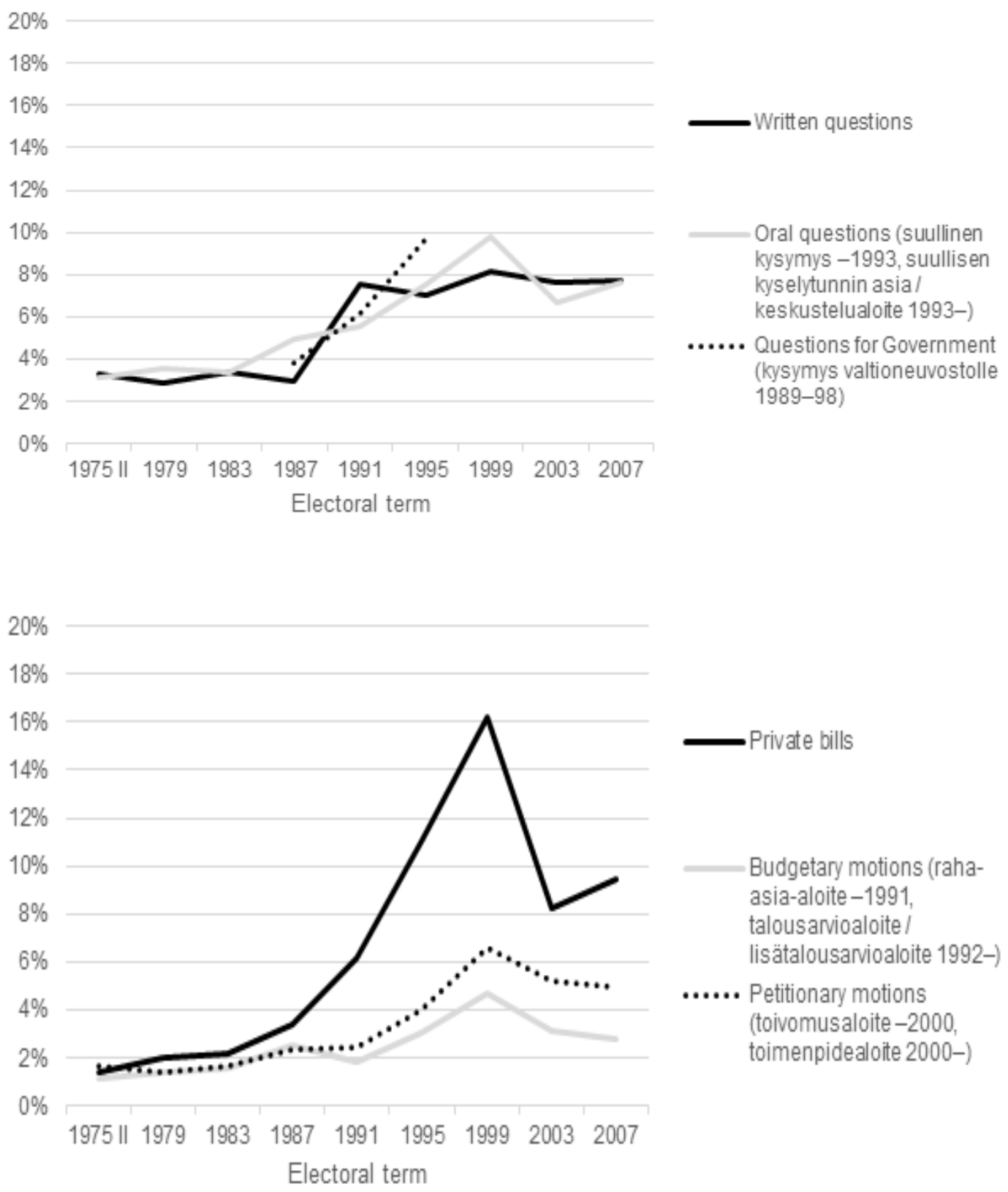

Figures 1 and 2. The share of parliamentary questions and motions concerning criminal policy in parliamentary seasons 1975 II to 2010.

The rest of the results concern this second content analysis. Quantitative increase in its data of 1589 written questions began during the four-season electoral term which started in 1991 (Figure 3). This, of course, only repeats the result shown in Figure 1. However, two reservations should be made here. First, the absolute increase was greater than the 
increase in share in Figure 1 because the total number of written questions also increased. Second, the outlying numbers of questions by a single member of parliament, Sulo Aittoniemi, have been highlighted. Because of his extreme quantitative output together with his shifting party allegiances, this politician is always either excluded from or highlighted in the figures and tables that follow.

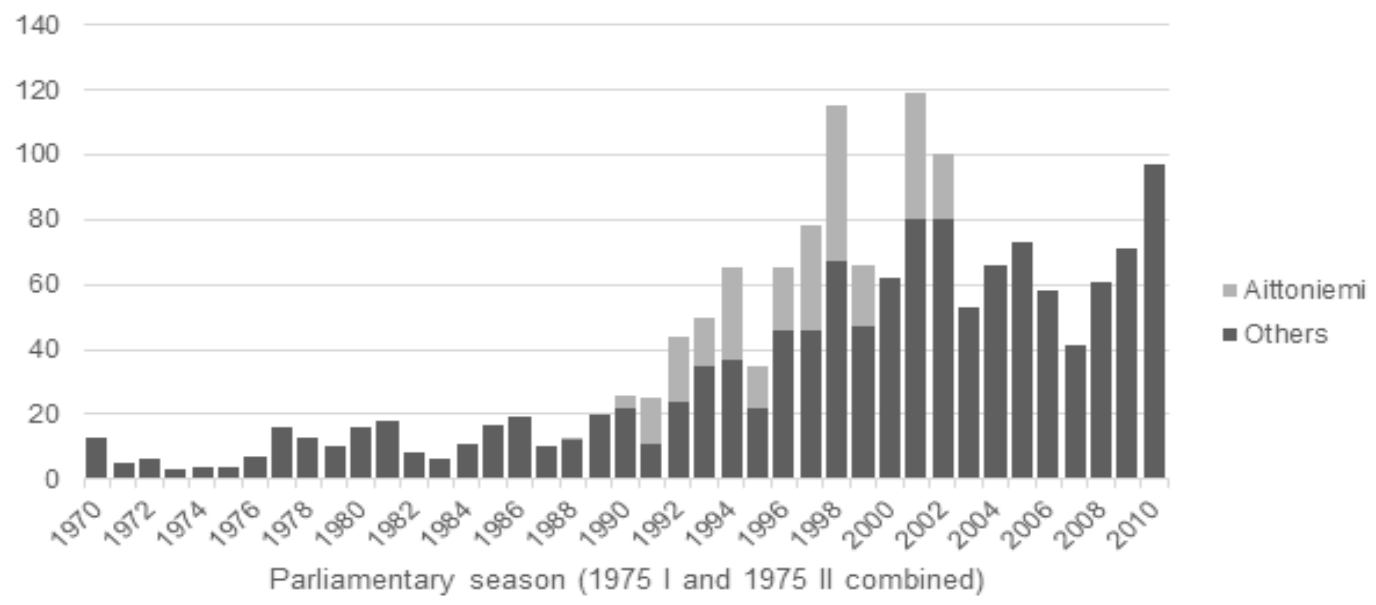

Figure 3. Written questions concerning criminal policy 1970 to 2010.

\subsection{Party Dynamics}

The second content analysis sheds added light on several aspects of the politicisation. The first of these is the role of different political parties in the development. Table 1 gives the share of four groupings of parties ${ }^{42}$ of the written questions for four decades. In creating the groupings, I considered trends in the numbers of questions between different parties, their general political alignment, ${ }^{43}$ and, to some extent, the characteristics of the questions posed by their representatives. The numbers of questions by the right-wing National Coalition Party developed differently from those of the conservative centrist Centre Party, Christian Democrats (formerly Finnish Christian League), and Finns Party (formerly Finnish Rural Party). The socially liberal Swedish People's Party, Green League, and Liberal People's Party differed from the latter ones with their more lenient stances.

42 If a question has been signed by members of several parties, it has been assigned to the party of its first signatory.

43 See e.g. Reunanen and Suhonen, Kansanedustajat ideologisella kartalla [Members of parliament on an ideological map], in Vaalit yleisödemokratiassa. Eduskuntavaalitutkimus 2007, eds. Borg and Paloheimo (Tampere University Press 2009) pp. 325-356, at 349. 
The role of the Social Democratic Party and the Left Alliance (formerly the Finnish People's Democratic League) in the development was distinctive. In general, the two leftwing parties combined controlled the most seats in the parliament, 'the conservatives' the second most, the Coalition party alone the third most, and 'the liberals' the fewest. The only exceptions were electoral terms 1991 and 2007, when the conservative grouping was the largest.

Table 1. The share of four groupings of parties of written questions concerning criminal policy 1970 to 2009 (excluding Aittoniemi).

\begin{tabular}{|l|r|r|l|r|r|}
\hline $\begin{array}{l}\text { Parliamentary } \\
\text { seasons }\end{array}$ & \multicolumn{1}{l|l|l|l|}{$\begin{array}{l}\text { Leftist } \\
\text { parties }\end{array}$} & $\begin{array}{l}\text { Liberal } \\
\text { parties }\end{array}$ & \multicolumn{2}{l|}{$\begin{array}{l}\text { Conservative } \\
\text { parties }\end{array}$} & \multicolumn{2}{l|}{$\begin{array}{l}\text { National } \\
\text { Coalition Party }\end{array}$} \\
\hline $1970-1979$ & $51,3 \%$ & $6,3 \%$ & $21,3 \%$ & $21,3 \%$ \\
\hline $1980-1989$ & $33,1 \%$ & $8,8 \%$ & $36,0 \%$ & $22,1 \%$ \\
\hline $1990-1999$ & $31,8 \%$ & $14,4 \%$ & $39,7 \%$ & $14,1 \%$ \\
\hline $2000-2009$ & $23,1 \%$ & $10,4 \%$ & $39,4 \%$ & $27,1 \%$ \\
\hline
\end{tabular}

Left-wing representatives submitted the majority of the written questions concerning criminal policy in the 1970s. Their share decreased to a third in the 1980s and 1990s, and below a quarter in the 2000s. While the electoral success of the Left Alliance in particular tended to wane during the period, this decrease in share of questions far exceeded the decline of the left's control of parliamentary seats. The conservative parties became the grouping with the largest share in the 1980s. Their share was the largest in all electoral terms from 1983 onwards. At first, the share of the liberal grouping with the smallest numbers of questions rose as well. In the 2000s, however, the National Coalition Party increased its share so that the combined share of the leftists and the liberals decreased to approximately a third. The overall impression is that as the political salience of crime increased, the political initiative concerning crime control moved away from the liberal left towards the conservative right. The politicisation was pioneered by the conservative parties, whose activity had increased already in the 1980s. Along with the politicisation, criminal policy increasingly became a discursive field dominated by the conservative right. The transformation was significant compared to the 1970s, when the relative activity of the left was much stronger.

During the period of electoral terms 1979 to 2007, when government coalitions were stable, a small majority (53\%) of all written questions concerning criminal policy (excluding Aittoniemi) were submitted by members of the opposition. All governments in that period had a majority, which adds to the relative activity of members of the opposition. The share of the opposition notably peaked in the 1991 electoral term. Of the three 
largest parties by seats, the rise in the number of questions co-occurred with the start of a term in opposition in the cases of the Social Democrats (1991) and the Centre Party (1995), but not in the case of the Coalition Party. Based on my general observations of the data, of these three parties, the number of questions by the Centre Party seems to have somewhat reflected their fortunes in reaching a position in the government (being higher during opposition terms and lower during government terms), overall. This could be due to pressure on the Centre Party, when out of power, to follow the lead of the small but active Christian Democrats and Finns Party, who sat mostly in the opposition in the 1990s and 2000s. However, the relative share of written questions concerning criminal policy did not peak during electoral years, which speaks against the possible hypothesis that crime rhetoric has been used strategically merely to gain power.

Next, I will analyse the development of the broad policy stances of individual parties. This requires the introduction of the variable of policy direction. The written questions were coded with a direction according to the policy measure they proposed or dealt with. I defined as 'toughening' the questions which demand:

- more powers, measures, resources, staff, equipment, performance enhancing training, or information available to actors in the field of crime control, such as the police;

- less regulation or oversight of those actors;

- boosting the efforts of those actors;

- harsher sentencing scales or sentencing practices;

- replacing a sanction with a harsher one;

- criminalisation;

- longer statutes of limitation or lower age of criminal responsibility;

- more coercive treatment for offenders;

- or increased financial liability of offenders towards the state.

These questions, which for the sake of pithiness I call 'toughening', also include questions which merely demand to secure existing levels of control. I interpreted as 'softening' questions which, reversely, demanded either a decrease of control or merely the maintaining of limits on it. When interpreting the results, a certain asymmetry between these two stances should be appreciated: In practice, when a politician demands tougher measures, it often means offering them as a solution to a perceived social problem. However, when a politician demands softer measures, the issue is usually the toughness of control or a specific criminalisation in itself. Questions which suggested other measures or suggested none were coded as without a policy direction.

Figure 4 depicts the development of the share of toughening questions among the six parties whose representatives wrote the most questions concerning criminal policy. The 
shares of toughening questions among the questions by the Left Alliance and the Social Democratic Party rose each decade and surpassed 50 percent in the 2000s. With the three conservative centrist parties, the shares of toughening questions rose very high in the 1980s, but fell somewhat for the next two decades. The share of toughening questions by the National Coalition Party was stable. The conclusion of the development is that dispersal between the six parties became much smaller in the 1990s and 2000s than before. While the evidence is of a very general level, it indicates that the politicisation driven by the conservative and right-wing parties drew the two left-wing parties to approach them in tone. Crime control did not only become politicised, but the political messages of different parties became more uniformly tough at the same time. The peak in the share of questions by the conservative parties that were toughening in the 1980s further underlines their role as the trailblazers in the politicisation. Together, the politicisation and the depolarisation demonstrate that the will to resort to crime control as a societal instrument in solving various social problems increased, and that this decreasingly distinguished the political aisles from each other as the left began to join the conservative right in the 1990s.

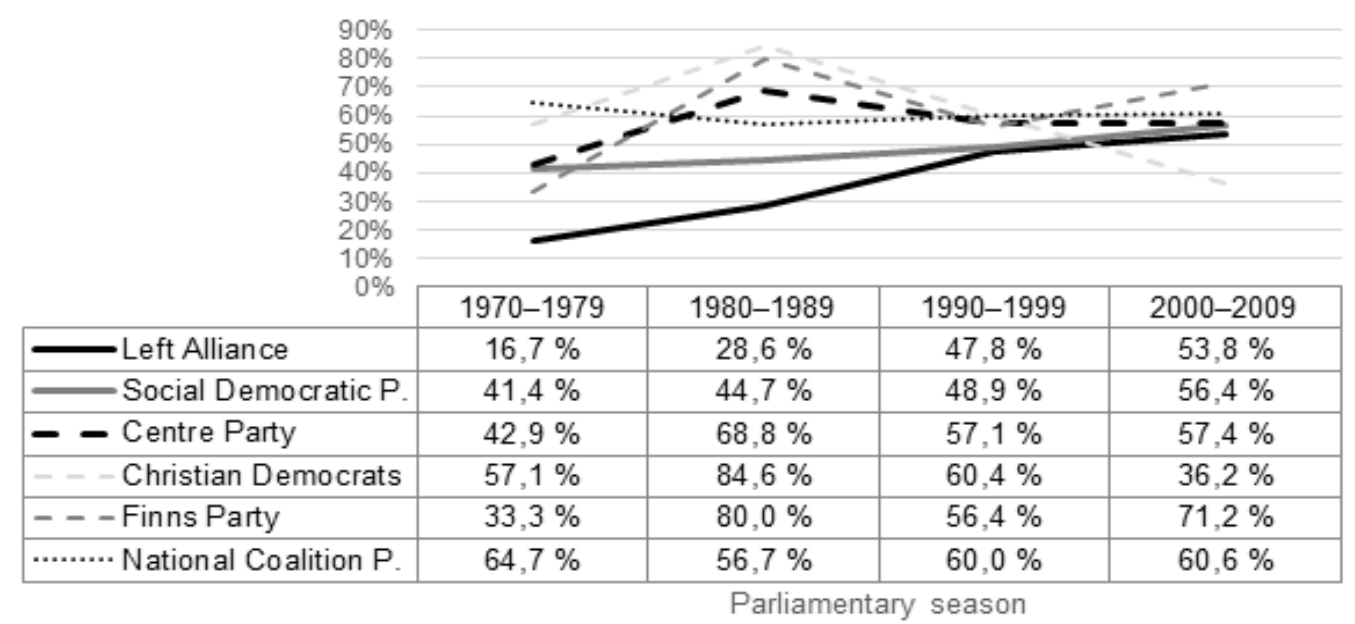

Figure 4. Share of written questions suggesting a toughening measure of questions concerning criminal policy by six parties 1970 to 2009 (excluding Aittoniemi).

\subsection{Politicisation and Legislative Change}

The remaining results concern the relationship of the politicisation to legislative development, first from the perspective of the policy direction indicated by the data. Overall, the share of toughening demands was lower in the data in the 1970s than in the 1980s, 1990s, and 2000s. The share of softening demands fell from under a fifth in the 1970s and 1980s 
to under a tenth in the 1990s and 2000s. Stances became tougher. Although the rhetoric used in the questions tended not to be particularly sharp or emotional in my opinion, I noticed that the concept of 'the public sense of justice', and the emphasis that sentences should match up to it, appeared in the questions in the late 1990s. At the same time, the legislative direction as quantified by Lappi-Seppälä ${ }^{44}$ changed from softening in the 1970s and 1980s to ambivalent in the 1990s and 2000s (Table 2). All but one of the softening changes in the 1990s and 2000s concerned sentencing and sanctions in general. The use of community sanctions and parole instead of imprisonment was increased, and imprisonment for fine default was limited. All toughening changes concerned specific offences. As crime control became politicised, demands concerning it became harsher, too, yet toughening demands were the most common ones in the 1970s as well; that crime control was not a privileged instrument of social regulation in the minds of politicians in the 1970s was primarily expressed by silence about it. Crime control becoming politicised meant it was being appealed to as a solution in increasing numbers of instances. Thus, while the direction of the change in the question data and the change in legislative development were the same, the shares of softening and toughening demands and softening and toughening legislative changes were consistently quite distinct from each other. This observation qualifies the quantitative politicisation of crime control as a phenomenon, and makes it reasonable to assume that it is associated with a relatively more punitive direction in legislative development-as indeed it was.

Table 2. Shares of written questions concerning criminal policy by policy direction (excluding Aittoniemi) and significant legislative changes by direction, 1970 to 2009.

\begin{tabular}{|l|l|r|r|r|l|l|}
\hline $\begin{array}{l}\text { Parliamentary } \\
\text { seasons }\end{array}$ & $\begin{array}{l}\text { Number } \\
\text { of written } \\
\text { questions }\end{array}$ & $\begin{array}{l}\text { Softening } \\
\text { demands }\end{array}$ & $\begin{array}{l}\text { Other } \\
\text { demands } \\
\text { or none }\end{array}$ & $\begin{array}{l}\text { Toughening } \\
\text { demands }\end{array}$ & $\begin{array}{l}\text { Softening } \\
\text { legislative } \\
\text { changes }\end{array}$ & $\begin{array}{l}\text { Toughening } \\
\text { legislative } \\
\text { changes }\end{array}$ \\
\hline $1970-1979$ & 81 & $17,3 \%$ & $38,3 \%$ & $44,4 \%$ & 8 & 0 \\
\hline $1980-1989$ & 137 & $19,0 \%$ & $22,6 \%$ & $58,4 \%$ & 4 \\
\hline $1990-1999$ & 357 & $7,8 \%$ & $38,1 \%$ & $54,1 \%$ & 4 & 3 \\
\hline $2000-2009$ & 645 & $9,1 \%$ & $37,7 \%$ & $53,2 \%$ & 3 & 4 \\
\hline
\end{tabular}

Finally, to further assess connections between the politicisation and amendments to criminal law, I will compare attention given in the data with legislative change ${ }^{45}$ concern-

44 Lappi-Seppälä, Nordic Sentencing, 45 Crime and Justice (2016) pp. 17-82, at 73.

45 See Lappi-Seppälä 2013 pp. 51-52. 
ing the three types of offences mentioned as the foremost areas of the 'punitive turn': drugs, violence, and sex crimes. All three topics stand out in the data, but initially when the number of questions started to rise in the 1990s, the attention of members of parliament-the Social Democrats in particular-focused most on economic and property crime. Coverage of economic and property crime peaked in the media in the mid-1990s, too. ${ }^{46}$ The attention of the Social Democrats then switched to drug crimes. The Coalition Party and Christian Democrats were at the vanguard regarding the rise of the themes of violence and sex crimes.

In the following figures concerning the three types of crimes, for each parliamentary season I have aggregated the questions from that season and the three preceding seasons. This style evens out variations caused by differences in the length of parliamentary seasons during an electoral term and illustrates the accumulation of political pressure towards legislative changes. I will also compare the development in the numbers of questions to recorded crime (Statistics Finland), which could hypothetically influence politicians' picture of whether crime is increasing. As in the media, ${ }^{47}$ the topic of drugs was present the most in written questions at the turn of the millennium (Figure 5). Questions concerning drugs were not particularly oriented to punishing. Regarding measures, drug rehabilitation as well as increasing police powers and drug testing were commonly promoted. The integration of narcotics offences into the Criminal Code in 1993 preceded the rise of the theme. The remaining three toughening legislative changes concerning drugs, however, occurred during the peak years: Drug control was tightened in prisons in 1999, in 2001 giving fines for drug use was made easier, and a zero limit was set for drug intoxication in traffic in 2003. The content of the questions as well as the latter three changes perhaps reflect a similar preference for catching more people over harsh sentencing. The huge increase in recorded crime is connected to increased policing. ${ }^{48}$ Nevertheless, there was real increase at least in the use of cannabis. According to surveys, concern about the drug problem and fear of facing violence because of drug use rose from 1996 to 2002 but then fell..$^{49}$ It seems unlikely that the increase in drug use in the 1990s would have been so visible as to explain the panic of the late 1990s and early 2000s. Increased policing along with the concern the public, the media, and politicians felt about drugs likely amplified each other creating a feedback loop.

46 Kemppi 2002 pp. 52-54; Kemppi and Kivivuori 2004 pp. 10-11; Kivivuori, Kemppi, and Smolej 2002 pp. $75-77$.

$47 \quad$ Ibid.

$48 \quad$ Kinnunen 2008 p. 80.

49 Metso, Winter, and Hakkarainen, Suomalaisten huumeiden käyttö ja huumeasenteet. Huumeaiheiset väestökyselyt suomessa 1992-2010 [Finns' drug use and drug attitudes. Drugthemed population surveys in Finland 1992 to 2010] (Terveyden ja hyvinvoinnin laitos 2012). 


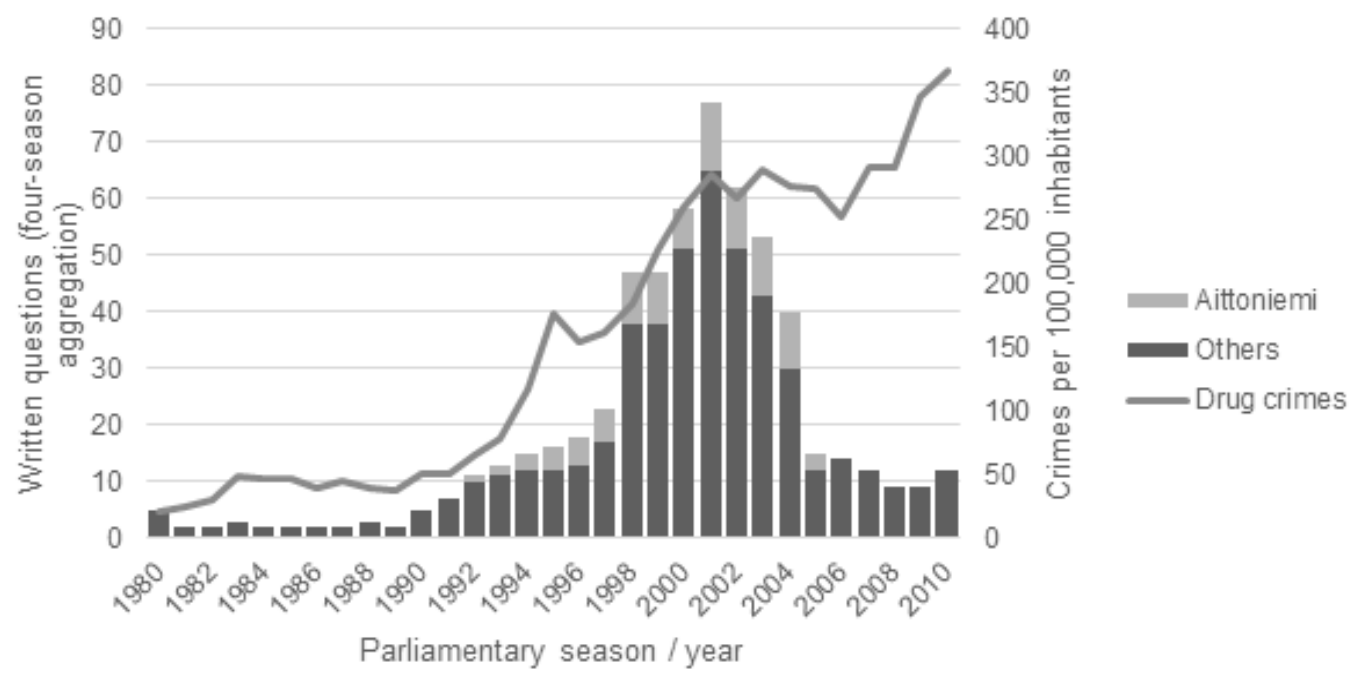

Figure 5. Written questions concerning drugs and recorded drug offences 1980 to 2010.

Violence and sex crimes dominated the crime headlines of Finnish tabloids from the mid-1990s onwards. ${ }^{50}$ In the editorials of the broadsheet Helsingin Sanomat, the themes of domestic violence and sex crimes became prevalent at the end of the 1990s. The editorials claimed violence was on the rise and becoming increasingly brutal. ${ }^{51}$ These two themes surfaced significantly in the data of this analysis also (Figures 6 and 7). Domestic violence was made a matter of public prosecution in 1995. This preceded the rise of the theme of violence in the data; however, the peak period of the early 2000s saw the raising of the minimum sentence for aggravated assault (2001) and the limiting of grounds for non-prosecution in cases of domestic violence (2004). A fourth change in 2011 increasing penalties for domestic violence was preceded by a new rise in the number of questions. In regards to sex crime on the other hand, all five toughening legislative changes 1970 to 2011 occurred after the surfacing of this theme in the data in the 1990s. Penalties for rape were increased in 1999 and again in 2011, penalties for procuration and child pornography were increased in 2005, a limited criminalisation of the purchase of sex was enacted in 2006, and penalties for the sexual abuse of children were increased in 2011. The tone of the questions concerning sex crimes was more punitive compared to violence (and even more so compared to drugs). Tougher punishments were advocated relatively often. Recorded sex crime does not seem to have a connection to the politicisation. The rise of the topic may be related to growing cultural assumptions about the fragility of childhood. According to my notes, the majority of the questions concerning sex crimes 208, 213. 
concerned acts victimizing children. The number of recorded assaults rose but in a more even manner than the number of questions. According to victim surveys, which enable the total crime level to be assessed, experiences of physical violence did not increase from the 1980s to the 2000s. However, experiences of physical threat did increase. This disconnection might indicate a decreasing tolerance of violent behaviour. Fear of violence rose from 1988 to 1997 but fell afterwards. Both domestic violence affecting women and fear of domestic violence and sex crimes decreased. ${ }^{52}$

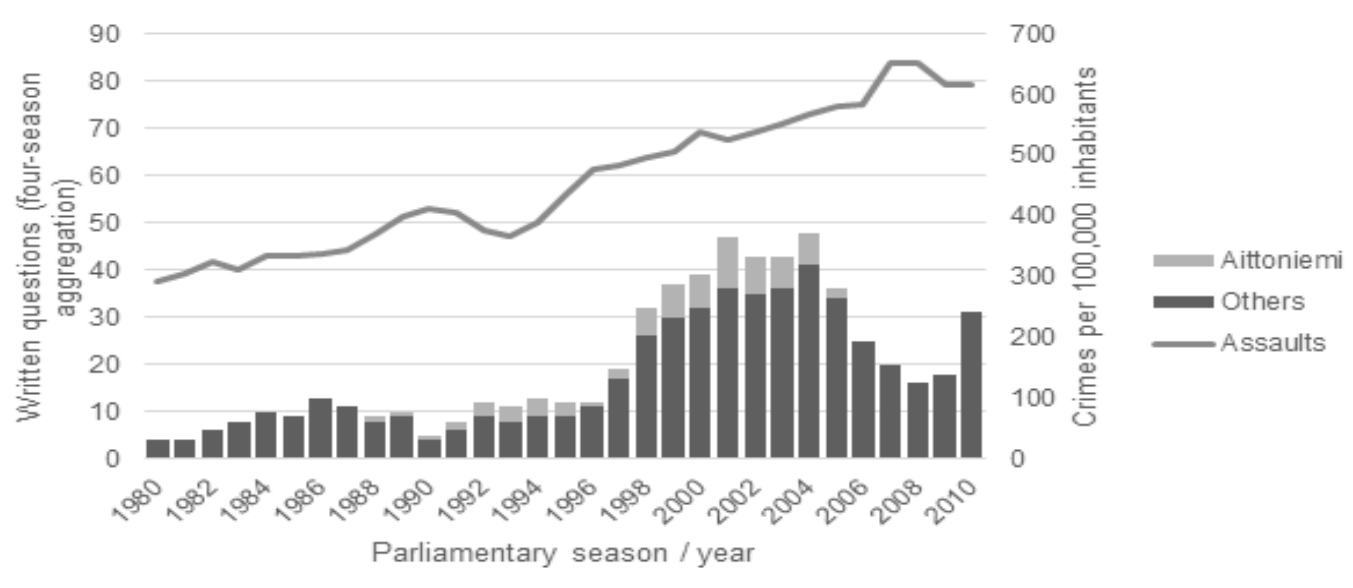

Figure 6. Written questions concerning violence and recorded assaults 1980 to 2010.

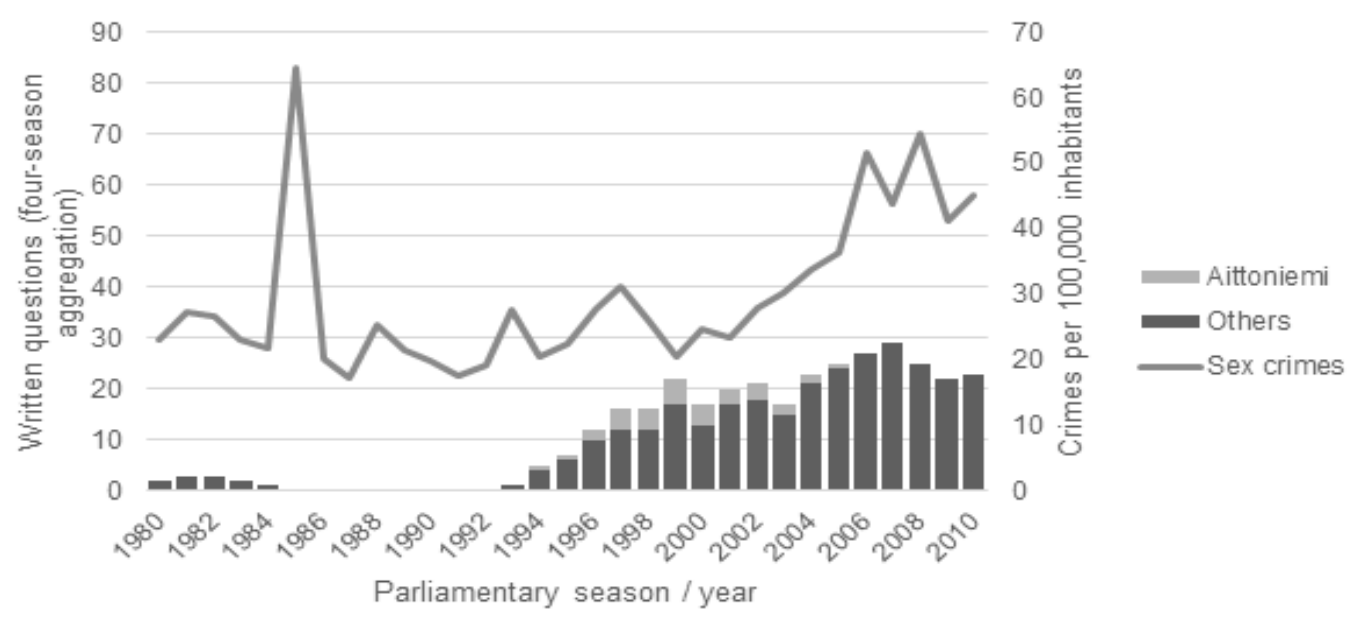

Figure 7. Written questions concerning sex crimes and recorded sex crimes 1980 to 2010.

52 Sirén, Aaltonen, and Kääriäinen, Suomalaisten väkivaltakokemukset 1980-2005. Kansallisen uhritutkimuksen tuloksia [Finns' violence experiences 1980 to 2005. Results of the national victim survey] (Oikeuspoliittinen tutkimuslaitos 2010). 
Summing up the findings regarding types of crime, political attention, too, was focused on economic and property crimes at the time in the 1990s when control of economic crime received increased notice in crime prevention programmes. The three areas of the punitive turn started to receive increasing attention towards the end of the decade. Most toughening legislative changes concerning drugs, violence, and sex crimes took place during periods of elevated political attention, which indicates that politicisation did matter. The conformity of the observations with media data supports their accuracy.

\section{Conclusions}

Criminal justice in Finland became politicised in the 1990s. The share of crime themes rose in all types of parliamentary questions and motions after the 1980s. The number of written questions concerning criminal policy rose significantly beginning in the early 1990s.

Polarisation concerning the general direction of criminal policy seems to have diminished. Traditional left-wing parties, which in the 1970s had the initiative in criminal policy, converged towards the conservative and right-wing parties in the share of toughening demands. The rise in the number of written questions in the 1990s was preceded in the 1980s by the growing initiative of the conservative centrist parties and a pronouncedly high share of toughening questions among these parties. Economic and property crime may have acted for the Social Democrats in the 1990s as a gateway to joining the conservative parties, which had pioneered the politicisation of the crime problem. Opposition parties are not particularly overrepresented in the data, but some timing details suggest that crime themes were occasionally used to challenge sitting governments. The party-politics of crime control in Finland deserve further historiography and analysis.

As softer lines of thought lost ground to tougher ones, legislative development switched from a restrictive trend towards ambivalence. Nevertheless, toughening demands were also more prevalent during the restrictive period: the data of this analysis and legislative change are at odds with each other in this manner throughout the period. Were one to presume a causal relationship with the political context the parliamentary data operationalises ${ }^{53}$ this observation stresses the independent significance of politicisation. The politicised manner of discussing criminal policy seems, in general, to have a bias towards toughness. From this perspective, the legislative trend was restrictive in the 1970s and 1980s because the politics of crime control were corporatist and committee-driven. The

53 For support see Seeberg, The opposition's policy influence through issue politicisation, 33 Journal of Public Policy (2013) pp. 89-107. 
way in which criminal policy is made in Finland became more politicised and therefore harsher in the 1990s. Of course, the imbalance is only to be expected, in the sense that tightening crime control can be offered as a solution to various social problems, unlike softening it, which is primarily a solution to the harshness of criminal justice. Alternative solutions to those problems that have, until that point, been met with harsh justice then need to be worked out independently. Criminal justice becoming politicised is, in fact, societal problem-solving taking a repressive orientation.

In the data of written questions, the rise was first associated with a focus on economic and property crime. Towards the turn of the millennium, the focus drifted towards the types of offence previously mentioned by Lappi-Seppälä to be the areas of the punitive turn in Finnish criminal justice: drugs, violence, and sex crimes. The conclusion is similar to Alvesalo's. The consistency between the results of previous studies on the Finnish media's crime coverage and its shifting focuses and my own results supports the idea that the data used in this analysis operationalises changes in a wider political discourse about crime control. Toughening legislative changes concerning the three offence types mostly co-occurred with high political attention, as measured by the question data.

\section{Discussion: The Changing Structure of Criminal Policy-Making}

In this closing section, I will analyse the turn in the 1990s in its institutional context. The purpose of leaving this discussion, which introduces some new literature, to the end is to avoid claiming that the explanations I suggest could be directly inferred form the data of the empirical analysis. Finnish scholars have given quite uniform explanations for the turn. The accepted list of reasons includes the recession, unemployment, retrenchments, neoliberalism, inequality, the collapse of the Soviet Union, and exposure to globalisation. ${ }^{54}$ Anxiety caused by economic insecurity and changing international relations was channelled into fear of crime. News about crime started to sell, and the increased coverage only worsened these fears. Politicians took up the matter of crime, which fed back to the media. Politicians acted and changed legislation. The dissolution of the Soviet Union and Finland's subsequent membership application for the European Union coincided with the turn. The new Russia appeared unstable, with news highlighting rampant Mafia-style crime ready to spread and infiltrate into Finland. Both the end of the Cold War and the enlargement of the European Union could culturally be understood as the victory of market liberalism and as the advent of a new era of increased individual responsibility. Social democratic parties in Finland and elsewhere where at least temporarily drawn towards the political centre (the so-called third way). Fulfilling the conditions for

54 See Kinnunen 2008 pp. 68-70, 72; Koskela 2009 pp. 33-34, 47-48, 67-68; Lappi-Seppälä 2013 p. 43; Sirén, Aaltonen, and Kääriäinen 2010 pp. 29-30. 
membership set boundaries to the making of domestic welfare state policy, but not to criminal law policy.

Without denying overdetermination or the contingent aspects of the turn, it would be possible to approach it in a more theoretical manner. In the beginning of this text, I gave a more favourable opinion regarding the idea of meaningful comparative differences in harshness between penal systems, and consequently the notion of Nordic exceptionalism, than some Nordic critics have. At the same time, I expressed reservation towards a cultural interpretation of this exceptionalism. Institutionalist explanations are open to the possibility of regional differences despite global technological developments, but are also more open to change than cultural ones. According to what could be described as the globalisation or Americanisation thesis in penology, here represented by Loïc Wacquant, punitive penality is an integral element of neoliberalism as it exists in the real world. Societies resort to penal policy as a replacement for the receding welfare state for both material and symbolic reasons: It is used to manage the excluded population as well as to reassure the insecure middle class and to normalise inequality ${ }^{55}$ Punitive policies are disseminated globally alongside other neoliberal policies. ${ }^{56} \mathrm{Neo}$-institutionalist comparative criminal justice explains differences in criminal justice by reference to institutional context, which filters such global developments. ${ }^{57}$ Michael Cavadino and James Dignan associate the harshness of criminal justice with types of welfare state regimes (the strength of the welfare state), ${ }^{58}$ and Nicola Lacey similarly with the variety of political economy (level of non-market coordination in the economy). ${ }^{59}$ The inverse relationship between welfare state expenditure and imprisonment rates has been shown multiple times. ${ }^{60}$

Interestingly, comparative political research associates both the strength of the welfare state and the harshness of penal policy with models of democracy. Inclusive softness correlates with corporatist consensus democracy and exclusionary toughness with pluralist majoritarian democracy. In Arend Lijphart's classification, majoritarian democracy is typified by minimal-winning majority governments (as opposed to minority governments or 'oversized' majority governments), executive dominance, a two-party system,

55 Wacquant, Punishing the Poor. The Neoliberal Government of Social Insecurity (Duke University Press 2009).

56 Wacquant, The global firestorm of law and order: On punishment and neoliberalism, 122 Thesis Eleven (2014) pp. 72-88, at 76-79.

57 See esp. Lacey, The Prisoners' Dilemma. Political Economy and Punishment in Contemporary Democracies (Cambridge University Press 2008). See also Wacquant 2014 p. 79.

$58 \quad$ Cavadino and Dignan, Penal Systems. A Comparative Approach (SAGE 2006).

$59 \quad$ Lacey 2008.

60 E.g., Downes and Hansen, Welfare and Punishment in Comparative Perspective, in Perspectives on Punishment. The Contours of Control, eds. Armstrong and McAra (Oxford University Press 2006) pp. 133-154; Lappi-Seppälä, Trust, Welfare, and Political Culture: Explaining Differences in National Penal Policies, 37 Crime and Justice (2008) pp. 313-387. 
majority elections, and interest pluralism. Consensus democracies are typified by coalition politics, strong parliaments, a multiparty system, proportional representation, and corporatism. Based on statistical evidence, he claims that consensus democracies are systematically 'kinder', as measured by social expenditure and criminal justice as well as foreign aid and environmental protection. ${ }^{61}$

The pioneer of sociology of criminal law, Émile Durkheim, also drew connections between institutional structure and regulatory repression. Durkheim's theory of democracy resembled the contemporary theory of consensus democracy. According to Durkheim, democracy does not mean the measurement of majority opinion, but inclusive and deliberative will-formation, and founding the legitimacy of decision-making on the state's ability to communicate with the public. Perhaps the centremost thesis of Durkheim's sociology was that the cohesion of human communities, without exception, relies on regulation. Durkheim contrasts repressive criminal law regulation-which he associates with traditional homogenic communities on the one hand, and absolutist state power on the other-with restitutive welfare state regulation, which has the potential to become the new dominant existential regulatory foundation for functionally differentiated societies. He considers corporatist participation a central structural component of a modern democracy capable of realising this. Corporations (functional social organisations such as trade unions) are structurally compatible with modern societies and work as substitutions for traditional communities. Corporations themselves create restitutive regulation fitting the logic of a modern society. They also democratise the state by bridging the gap between the state and the individual and by facilitating communication between them. This democratised relationship with the individual gives the state a social purpose as the guarantor of individual social rights and promoter of individual autonomy, further decreasing individual dependence on traditional communities and their role as producers of social mores. In short, whether modern societies rely more on repressive regulation or welfare state regulation for social solidarity is conditioned by the political system. ${ }^{62}$

Consensus characteristics in Lijphart's terms weakened in Finnish politics in a process which started in the 1980s. This was marked by rising executive dominance, decreased willingness to build large item-specific coalitions, and the decline of democratic corporatism. That said, proportional representation and its associated multiparty system have survived untouched. Parliamentary power concentrated in majority governments lasting 2nd ed. (Yale University Press 2012).

62 See Durkheim, Professional Ethics and Civic Morals (Routledge \& Kegan Paul 1957). See also Durkheim 1933. 
full electoral terms and procedural changes increased their legislative force. ${ }^{63}$ The work of parliamentary select committees became subordinate to governmental platforms. ${ }^{64}$ The pursuit of inclusive coalitions in a democracy requires the acceptance of dissensus and its arbitration as the starting point for decision-making. By contrast, in a majoritarian system, the majority can decide without regard to the minority. The weakening of consensus characteristics has increased the value of attaining a governmental position, which in turn requires uncompromising acceptance of majority positions. Perhaps paradoxically, the weakening of consensus characteristics has thus caused a decrease in realistic policy alternatives. ${ }^{65}$ The weakening of corporatist political participation is manifested particularly by the decline of the committee drafting of legislation. Committees were places for political inclusion, conciliation, and deliberation, and maintained the role of social organisations as intermediary institutions. ${ }^{66}$ The volume of committee drafting started to decrease in the 1980s and plummeted in the 1990s. The working groups that have partially replaced them are more dependent on the government's assignment and steering by civil servants. ${ }^{67}$ Political parties have changed from mass parties governed by their organisations to centrally led electoral parties. ${ }^{68}$

The strengthening of welfare state regulation and the humanisation of legal and criminal policy in Finland were founded on a participatory and deliberative corporatist democracy. The structures of Finnish democracy have, however, since changed from ideal-typical consensus democracy towards a more mixed system. This co-occurred with the end of the expansionist phase of the welfare state and the end of the restrictive phase

${ }_{63}$ Nousiainen, Suomalaisen parlamentarismin kolmas kehitysvaihe: Konsensuaalinen enemmistöhallinta, vireytyvä eduskunta [The third developmental stage of Finnish parliamentarism: consensual majority rule, reinvigorated parliament], 42 Politiikka (2000) pp. 83-96.

64 Mattila, Valiokuntalaitos [The institution of select committees], in Eduskunta. Kansanvaltaa puolueiden ja hallituksen ehdoilla, eds. Raunio and Wiberg (Gaudeamus 2014) pp. 119-131.

65 See Paloheimo and Raunio, Suomen puolueiden nykytila ja tulevaisuuden haasteet [Current state and future challenges of Finnish parties], in Suomen puolueet ja puoluejärjestelmä, eds. Paloheimo and Raunio (WSOY 2008) pp. 209-219, at 212-216.

66 Rainio-Niemi, State committees in Finland in historical comparative perspective, in Nordic Associations in a European Perspective, eds. Alapuro and Stenius (Nomo 2010) pp. 241-267.

67 Pakarinen, Lainvalmistelu vuorovaikutuksena. Analyysi keskeisten etujärjestöjen näkemyksistä lainvalmisteluun osallistumisesta [Law drafting as interaction. Analysis of the views of prominent interest organizations concerning participation in law drafting] (Oikeuspoliittinen tutkimuslaitos 2011) pp. 30-36.

68 Sundberg, Puolueiden organisaatiot ja suhteet etujärjestöihin [The organizational forms and interest group relations of parties], in Suomen puolueet ja puoluejärjestelmä, eds. Paloheimo and Raunio (WSOY 2008) pp. 61-83. 
in criminal justice. ${ }^{69}$ Societal regulation and the building of social solidarity have taken a relatively more repressive orientation as expressed by the politicisation of crime control and by legislative change.

As concluded in this study, the turn in the 1990s was associated with the politicisation of crime control. The new politicised structure of criminal policy-making stood in contrast to the preceding committee-driven one. The two structures produced different legislative output. In contrast to Pratt's concept and model of penal populism, the novel feature in Finnish criminal policy-making was hardly the increased influence of non-governmental organisations in law-making, which in Finnish corporatism would not have been something new. Instead, the drafting of legislation has become increasingly driven by the executive and the civil-servants. This has been true for law-making in general. In the specific case of criminal law drafting this has meant primarily a declining role of academic experts. If criminal justice in Finland used to be more 'technocratic' in this sense, this was not because it was considered too important for the people to decide, but because it was too marginal a subject to invoke broader social deliberation.

Many overlapping factors are at play here, and most of them are not exclusive to Finland. Institutions may filter global developments imperfectly and be subject to influences and gradual change themselves. Establishing causal directions is hard. Similar developments in criminal policy to those in Finland from the 1990s onwards have been recorded in Scandinavia as well, ${ }^{70}$ although the criminal political histories of the Scandinavian countries have been less volatile. Has there been a similar democratic development behind similar criminal justice developments in the rest of the Nordic countries as well? The decline of democratic corporatism and growing executive power are certainly sometimes seen as broader trends among Western countries. The criminal policies of the Nordic countries have become quite convergent with each other, but this has not always been the case. Present similarities are better explained as reflecting contemporary patterns of communication and geopolitical proximity, rather than by referring to shared cultural roots and continuity. As the historical case of Finland shows, the Nordic countries are not culturally immune to harshness. Nordic exceptionalism has been founded on an institutional assemblage which relieves social reliance on penal exclusion, and which is not immutable.

69 See also Kekkonen, Suomen oikeuskulttuurin suuri linja 1898-1998 [Broad lines of Finnish legal culture 1898 to 1998], in Suomen oikeuskulttuurin suuri linja. Suomalainen lakimiesyhdistys 100 vuotta, (Suomalainen Lakimiesyhdistys 1998) pp. 1-183, at 100-112, 131-141.

70 See e.g. Tham, From treatment to just deserts in a changing welfare state, in Beware of Punishment. On the Utility and Futility of Criminal Law, ed. Snare (Pax 1995) pp. 89-122. 